2012

\title{
Book Review: Cross Purposes: Pierce v. Society of Sisters and the Struggle over Compulsory Public Education
}

Amy Lynn Dee

George Fox University, adee@georgefox.edu

Follow this and additional works at: https://digitalcommons.georgefox.edu/soe_faculty

Part of the Education Commons, and the Religion Commons

\section{Recommended Citation}

Dee, Amy Lynn, "Book Review: Cross Purposes: Pierce v. Society of Sisters and the Struggle over Compulsory Public Education" (2012). Faculty Publications - School of Education. 203.

https://digitalcommons.georgefox.edu/soe_faculty/203 


\section{Paula Abrams}

\section{Cross Purposes: Pierce v. Society of Sisters and the Struggle}

\section{over Compulsory Public Education}

Ann Arbor, MI: University of Michigan Press, 2009 hb 280pp \$70

ISBN 978-0-472-11700-0

Contradicting the unappealing cover and stodgy title, Abrams has crafted an engaging and revealing narrative connecting politicians, Klansmen, Masons, the Vatican, educators, parents, and citizens into an account that borders on intrigue but also elucidates and interprets the birth and defeat of a movement that resulted in landmark legislation. The book moves far beyond an explanation of Pierce v. Society of Sisters and provides an inside look at the major players and the motivations behind the Oregon School Bill. Readers witness the unbridled bigotry and hubris of the individuals supporting the School Bill in the early 1900s in Oregon and perhaps will wonder how it could have possibly unfolded as Abrams reveals. While this account begins and ends in Oregon, the short life of the School Bill, and its eventual overturn in the Supreme Court by way of Pierce $v$. Society of Sisters, in fact the path of the bill and its influence journeyed to another continent and reached into the future.

Educators reading Abrams's work will appreciate the focus on education and the societal factors shaping schools in the early 1900s. The influx of immigrants to America tested the prevailing attitudes about patriotism that had risen following the Great War. Homogeneity, while never a founding principle of this nation, emerged during this time as an ideal that defined and shaped the purpose of school. Compulsory education served as a means to assimilate, acculturate, and "Americanize" immigrants. Politicians viewed the educational system as assurance that democratic doctrine would endure. The political backing and deep involvement of the Ku Klux Klan in the development of the School Bill, and in the campaign to assure its passage, might shock those new to education or those who have not been exposed to the history of Oregon during the bill's inception. Behind the guise of ensuring the best education possible for all children, the bigotry driving the School Bill aimed daggers squarely upon private schools-primarily those offering a Catholic education to students. These and other private schools were accused of providing substandard education to the 12,000 who attended them, and the KKK promoted the bill on the grounds that it would guarantee equal education for all students as well as promote American values.

Political enthusiasts will appreciate Abrams's clear exposé of the direct connection between Oregon Klansmen and Masons and the political leaders of that time. Unlike other states with greater ethnic diversity, Oregon's anti-Catholic sentiment during a period of widespread immigration was enough to give Klansman a sphere of influence in local politics. The School Bill appealed to Republican voters, and Klansmen and Masons supported Republican candidates. The Republican governor, Ben Olcott, however, made clear his anti-Klan sentiments. This placed the School Bill supporters in a quandary. When Walter Pierce, a Democratic gubernatorial candidate, announced his support of the School Bill, the Klan had the candidate they needed to pass the bill. The political twists and turns, manipulations and calculations, and surprises and disappointments take on life and bring genuine interest to Abrams's work, even for those who might find politics mundane. 
Abrams, a professor of law, gives ample time to the connections between several key legislative decrees supporting or leading up to the School Bill and, eventually, Pierce v. Society of Sisters. The reader cannot miss the passionate interest Abrams holds in the legislation and the historical events preceding its legal trial. Oregon was not the first state to attempt such legislation, and Abrams guides the reader through the failed attempt in Michigan before briefly discussing other states that considered such measures. One will make connections between movements of almost a hundred years ago to the English-Only movement today. Abrams discusses the political and legal challenges to the passage of the School Bill and then gives the reader a thorough account of the players and the path the law took all the way to the Supreme Court. The strategy to use parental rights as a key argument for the plaintiff emphasizes the still-profound belief that parents, rather than the state, are best suited to make decisions regarding the child. Arguments on behalf of both the plaintiff and the state give the reader remarkable insight to the thinking, dispositions, and attitudes of those representing and hearing the case.

It is precisely those dispositions and attitudes in this historical account of Oregon that many might rather forget. Those who love reports and narrative from times past might very well read Abrams's book in one sitting, but it will require a stoic stance to keep emotions in check. Indignant outrage can only characterize the mind-set once the reader comes to terms with an Oregon history steeped in bigotry. While racism and intolerance continue to permeate much of society, we easily forget the influence of these abhorrent traits upon the foundations of political, legal, and educational systems. Destined as a classic, Abrams's work gives us a story of our not-so-distant past that requires us to ask, "What has changed, really?" 